реально сложившихся гарантий, отражающих в своей совокупности качественные характеристики правовых форм деятельности уполномоченных субъектов.

К числу особых признаков процедурного режима, прежде всего, необходимо отнести его связь с конкретным отраслевым методом и способом правового регулирования, которыми и устанавливаются элементы своеобразия в процессе реализации отраслевого вида ответственности.

Процессуальный режим - явление сложное, многогранное и имеет свою собственную структуру, включающую в себя принципы как социальные ориентиры, определяющие характер процессуальной деятельности и юридические гарантии, трактующиеся как организационно-правовые средства и способы, с помощью которых осуществляется эта деятельность и достигается строгое и неуклонное соблюдение и исполнение законов, обеспечивается охрана прав и законных интересов всех участников процесса, возможности проявление их правовой активности. Устанавливая различия между процессуальными принципами и гарантиями, следует основываться на наличии между ними тесных взаимообусловливающих связей.

На основании вышеизложенного, необходимо сделать следующий вывод, что процессуальная форма представляет собой одну из фундаментальных категорий права, воплощенной в системе взглядов и положений, реализующейся в качестве основы теоретического исследования организационных аспектов процессуальной деятельности, критерия оценки законодательства и фактора формирования судебной практики. Процессуальная форма позволяет организовывать участников процесса, обеспечивать реальную защиту прав граждан и организаций, вовлеченных в судебный процесс, и минимизировать возможности произвола со стороны как любых внешних по отношению к процессу лиц, так и его участников, в том числе самого суда, путем детальной регламентации порядка рассмотрения и разрешения судебных дел, производства отдельных процессуальных действий и в известной мере последовательности их осуществления, а также исчерпывающей регламентации процессуальных прав и обязанностей каждого из субъектов сложных и многогранных процессуальных отношений.

$$
* * *
$$

1. Лазарева В.А.Уголовный процесс: учебник / под ред., Юношев С.В., Шуваткин А.В., Шестакова Л.А., Шейфер С.А., Таран А.С., Савельев К.А., Развейкина Н.А., Проскурина Т.Ю. — Москва: Юстиция, 2021. $432 \mathrm{c.}$

2. Матвеева, М.А. Теория правотворчества: методологические и концептуальные аспекты: монография / Матвеева М.А. - Москва: Русайнс, 2017. - 142 с.

3. Панкова, О. В. Теоретические основы правосудия по делам об административных правонарушениях: монография / О. В. Панкова. - Москва: Статут, 2020. - 232 с.

4. Свирин, Ю.А. Арбитражный процесс : учебник / Свирин Ю.А. - Москва : КноРус, 2021.- 528 с.

5. Чернявский, А.Г. Юридическая ответственность. Основные подходы в современной науке: монография / Чернявский А.Г. и др. - Москва :Русайнс, 2016. - 264 с.

6. Шакарян М. С. К вопросу о понятии и составе лиц, участвующих в гражданских делах / М. С. Шакарян //Труды Всесоюзного юридического заочного института. — М.: ВЮЗИ. — 1970 . — Том 16 Ч. 2 . — С. 160 195.

\title{
Кравцова Е.А. \\ Правовой и исторический аспект борьбы с коррупцией в РФ
}

Тихоокеанский Государственный Университет (Россия, Хабаровск)

doi: 10.18411/trnio-11-2021-245

\section{Аннотация}

Коррупция относится к числу наиболее опасных негативных явлений, которая препятствует преобразованиям в социально - общественной, экономической и 
государственно - управленческой сферах, порождает недоверие к власти и, в итоге, отрицательно сказывается на формировании имиджа страны на международной арене. Несмотря на то, что законы, посвящённые борьбе с коррупционными проявлениями создавались и на ранних этапах формирования современного российского государства, на сегодняшний день одним из основополагающих законодательных актов, посвящённых борьбе с коррупцией, является Федеральный закон от № 273 - Ф3 «О противодействии коррупции» [1].

Ключевые слова: коррупция, борьба с коррупцией, антикоррупционная деятельность, предупреждение коррупции.

\section{Abstract}

Corruption is one of the most dangerous negative phenomena, which hinders transformations in the socio-social, economic and public administration spheres, leads to distrust of the authorities and, as a result, negatively affects the formation of the country's image in the international arena. Despite the fact that laws dedicated to combating corruption manifestations were created at the early stages of the formation of the modern Russian state, today one of the fundamental legislative acts dedicated to the fight against corruption is Federal Law No. 273 - FZ "On Combating Corruption". corruption.

Keywords: corruption, fight against corruption, anti-corruption activities, prevention of

Проблема противодействия коррупции является одной из самых обсуждаемых тем среди руководящей элиты и граждан страны. По центральному телевидению все чаще слышно о новых способах борьбы с ней. Однако проблема не только не решена, но и остается крайне острой вплоть до настоящего времени. Следовательно, сегодня важной задачей является установление реальной картины коррупционных отношений в государстве, причинно-следственных факторов данного явлении и поиска конкретных путей ее решения $[7$, c. 56].

Борьба с коррупцией ведется со времен Древней Руси. «Первые упоминая о коррупции можно найти в первой Русской Правде IX века Ярослава Мудрого [8, с. 41]. В то время не существовало термина «коррупция», сам термин «коррупция» пришел из латинского языка и буквально означал подкуп, продажность, саморазложение. Использовался другой термин - «мздоимство». При этом, в то время мздоимство еще не являлось проблемой, а скорее являлось вполне легитимной частью общественной жизни. Это выражается в том, что чиновников содержали жители тех регионов, куда они были назначены.

За нарушение данного положения были установлены весьма жесткие наказания. Некоторые ученые считают, что Ярослав Мудрый был первым кто узаконил взяточничество путем принятия кодекса «Покон вирный», которым устанавливалось, что жители обязаны были содержать вирников, приехавших собирать виру. В то время вира представляла собой определенный налог, а не дань. Сам же вирник мог взять с жителей для себя лучшие продукты, товары или же определенную сумму золотом (серебром) [9, с. 227-230].

В Судебнике 1497 года Ивана III в первой же статье устанавливается: «а посулов бояром, и околничим, и диаком от суда и от печалованиа не имати; також и всякому судие посула от суда не имати никому [5, с. 103-110]».

Иван III считается одним из ярых борцов с коррупцией, так как при нем было осуждено «за посул» около 235 чиновников различных рангов. Однако же данные законодательные акты по каким-то причинам исполнялись выборочно.

Именно с XVI в. начали появляться в народе следующие поговорки: «Всяк подъячий любит калач горячий», «Земля любит навоз, а воевода принос», «Судьям то и полезно, что в карман полезло», «В суд ногой - в карман рукой» и другие. Первые же эффективные антикоррупционные меры начались в период правления Ивана IV Грозного. 
Многие историки, считают, что введенная Иваном IV Грозным опричнина, представляет собой один из эффективных способов борьбы с поголовно коррумпированным госаппаратом. В это время за взяточничество начала назначаться смертная казнь, установленная Судебником 1550 года [2, с. 107].

В дальнейшем все антикоррупционные кампании не имели значительного эффекта для страны вплоть до начала правления Петра I. Принято считать, что Петр I был непримиримым борцом с коррупцией. Однако его антикоррупционная кампания имела больше показательный характер, чем последовательный.

После Петра I, на престол взошла Екатерина I, которая решила продолжать активно бороться с коррупционерами. Всего она издала около 187 указов, посвященной данной проблеме, но главной ошибкой при введении данной коррупционной кампании, стало то, что она отменила государственное жалование чиновников низшего уровня, возвращая для них «систему кормления», что позволяло им безнаказанно брать взятки.

Александр II начал качественно новую борьбу с коррупцией. Так он впервые ввел практику декларирование имущества чиновников, посредством опубликования книг, где указывались данные государственного служащего, его должность, жалование, все имущество, приобретенное или полученное в дар, наследство, имущество его жены и другое. Данные публикации были общедоступны [6, с. 95-97]. Он издал новую редакцию Уложения о наказания уголовных и исполнительных в 1866 году, где внес пояснения и добавил комментарии к статьям о взятках.

При Николае II было издано новое Уголовное уложение, в котором были введены отдельные понятия «взяточничество» и «лихоимство».

Одним из первых в мировой истории законодательным актом, систематизировавшим борьбу с коррупцией, стало Уголовное уложение 1903 года. О том, что борьбе с коррупцией придавалось в то время очень большое значение свидетельствует, в частности, факт, что на лиц, виновных в коррупционных преступлениях, не были распространены милости (амнистия), даруемые Всемилостивейшим Манифестом от 11.08.1904.

Уголовное уложение 1903 года не только систематизировало нормы права по борьбе с коррупцией в Российской империи, но и в значительной степени изменило меры ответственности за данные деяния по сравнению с нормативно-правовыми актами XVIII-XIX веков.

1. Среди наказаний за взяточничество не стало смертной казни.

2. Были радикально переработаны и доработаны законодательные положения, касающиеся взяточничества, по сути, создан прогрессивный правовой фундамент борьбы с коррупцией.

3. Была введена уголовная ответственность за посредничество во взяточничестве, а через пять лет и за дачу взятки. Важное профилактическое значение имело и решение [3, с. 75-82].

Законодателя о необходимости доведения до граждан не только законодательных актов, но и решений Сената по применению норм закона о взяточничестве. Однако, несмотря на использование правительством подобного комплексного подхода, окончательное искоренение взяточничества в России не было осуществлено из-за наступившей революции 1917 года.

Любые ограничения, которые накладываются на человека, кроме тех, которые описывают конституционные свободы и права человека могут вызвать коррупционные действия. Последние накладывают ограничения не столько на обычных людей, сколько на органы государственной власти, выполняя роль защиты обычных граждан от несанкционированного использования должностных полномочий людей имеющих власть против людей ее не имеющих.

Информационное обеспечение граждан. Данный метод основан на обучении граждан законодательству с целью их саморазвития. Это позволит людям четко понимать свои права 
и обязанности, какие нарушения что должны за собой повлечь, как проходит судебная процедура и что в ней учитывается.

Открытость ведомственных систем. Данный метод позволяет отслеживать все происходящие изменения в определенной структуре по средствам удаленного сервера, что позволяет целиком исключить возможность организовать коррупцию. Огромным минусом подобной системы является охрана коммерческой тайны или обеспечение дополнительных мер по защите персональных данных граждан и секретных сведений в оборонных ведомствах и организациях.

Социальное обеспечение чиновников. Медицинское обслуживание, беспроцентные кредиты для покупки недвижимости, большая пенсия - всё это равносильно повышению заработной платы в государственном секторе, увеличивая потери чиновника в случае, если его поймают на коррупционной деятельности.

Введение электронных закупок. Приводит к усилению конкуренции, повышению прозрачности государственных расходов, а также противодействию коррупции в сфере расходования бюджетных средств, предотвращению сговора и коррупционных действий среди участников аукционов.

В настоящее время методы борьбы с коррупцией практически бездейственны, бессильны, бесполезны. Метод борьбы с коррупцией это психология будущего поколения, надо прицелиться на век вперед, чтобы достичь значительного результата.

В заключении хотелось бы сказать, что коррупция сильно мешает развитию мировой экономики в целом и, в большей степени, развитию экономики страны. Развитые антикоррупционные методы в основном малоэффективны. Для успешного развития в дальнейшем, одним из первых пунктов в списке приоритетов государства должна стать борьба с коррупцией.

$$
* * *
$$

1. Федеральный закон от 25.12.2008 № 273-Ф3 "О противодействии кор-рупции" // Российская газета, № 266, 30.12.2008.

2. Амара М.И. Противодействие коррупции в Российской Федерации. Библиография (1991-2016 гг. ) / М.И. Амара, Ю.А. Нисневич, Е.А. Панфилова. — М.: Издательство Юрайт, 2019. — 284 с.

3. Башилов В.В., Ирлишин В.И. Коррупция как социально-правовая проблема // Обеспечение прав человека в деятельности правоохрани-тельных органов, 2019. - С. 75-82.

4. Кузнецов А.А. Коррупция в истории России // Современные тенденции развития науки и образования, 2018. - C. 426-435.

5. Малека Ю.Н., Попова Д.С., Зейналов Т.И. История борьбы с корруп-цией в России // Политиконравственные механизмы противодействия коррупции, 2018. - С. 103-110.

6. Медникова А.И. Борьба с коррупцией // Наука через призму времени, 2018. - № 5 (14). - С. 95-97.

7. Правовые основы противодействия коррупции: учебник и практикум / А.И. Землин, О.М. Землина, В.М. Корякин, В.В. Козлов; под общ. ред. А.И. Землина. — М.: Издательство Юрайт, 2019. — 197 с.

8. Решетников М.М. Психология коррупции. Утопия и антиутопия: моно-графия / М.М. Решетников. — 2-е изд. - М.: Издательство Юрайт, 2019. - 101 с.

9. Сидоренко А.В. Феномен коррупции: исторический экскурс // Совре-менные проблемы социальногуманитарных и юридических наук: тео-рия, методология, практика, 2018. - С. 227-230.

\section{Кудрявцева Л.В., Грицай Д.В. \\ Правовой статус беженцев в международном праве}

Кубанский государственный аграрный университет им. И. Т. Трубилина

(Россия, Краснодар)

doi: 10.18411/trnio-11-2021-246

\section{Аннотация}

В статье авторы рассматривают правовой статус беженцев в международном праве. На основании изученных международно-правовых актов были обнаружены проблемы правового статуса беженцев, что является весьма актуальной проблемой, учитывая мировую 